\title{
The Relationship between Resiliency Index and Instability of the Marriage in Women: A Correlational Design
}

\author{
Nazanin Mahdinia $^{1}{ }^{*}$, Shokoh Navabi Nezhad ${ }^{2}$
}

\section{ABSTRACT}

Objective: This study was conducted aimed to evaluate the relationship between resiliency and instability of marriage in married students of Islamic Azad University of Abhar. Methodology: The study was correlational and random sampling was carried out. The studied sample in this study were including 200 students. In this study, Conner and Davidson Resilience Scale (CDRISC) and questionnaire of the instability rate of marriage was used. To analyze the data, Pearson correlation test and F-test was used. Findings: The results showed that there is a significant inverse relationship between resiliency and instability of marriage. Conclusion: These findings can be useful in the area of preventive interventions.

Keywords: Resiliency, The Instability Of Marriage, Divorce, Married Students

According to the available statistics and increasing in divorce, especially in urban areas and in Tehran and an increase in emotional divorces per each official divorce, worrying conditions and its implications culturally and economically are very alarming (Bankipour et al, 2012). Because 90 percent of divorce factors are including poor communication skills in solving marital problems, low tolerance to criticism and power in perceiving the partner (Bahari, 2012). As a result, resiliency is an important cause of vision that increases adapting capability of man in the face of difficulties and overcome it and thereby cause to achieve balance in threatening conditions. (Salimi Bejestani et al, 2010).

\section{METHODOLOGY}

The study is a survey research, and the research method is descriptive and correlational. The population of the study was including all women married students who were studying in the second semester of 2013 in Islamic Azad University of Abhar, and in the present study 200 students in the dormitory were selected randomly. In this study, the questionnaires of the

\footnotetext{
${ }^{1}$ M.A In Counseling Psychology, Islamic Azad University Abhar Branch, Abhar, Iran.

${ }^{2}$ Shokouh Navabi Nezhad; Professor, Kharazmi University, Tehran, Iran.

*Responding Author

(C) 2016 I N Mahdinia, S Nezhad; licensee IJIP. This is an Open Access Research distributed under the terms of the Creative Commons Attribution License (http://creativecommons.org/licenses/by/2.0), which permits unrestricted use, distribution, and reproduction in any Medium, provided the original work is properly cited.
} 
The Relationship between Resiliency Index and Instability of the Marriage in Women:

A Correlational Design

instability of marriage with the reliability of the scale of Cronbach's alpha of $93 \%$ and reliability coefficient was 70\% and Conner and Davidson questionnaire with the reliability of the scale of Cronbach's alpha of 0.89 and reliability coefficient of 83 was estimated.

\section{Statistical analysis method}

The data were analyzed using descriptive statistics and the results of the study are presented in tables and statistical analysis was performed in the second part. In order to analyze research data regarding the nature of the test (Pearson correlation and multivariate regression analysis) were used.

Table 1: indicators of descriptive variables

\begin{tabular}{|l|l|l|l|l|l|}
\hline $\begin{array}{l}\text { Statistical } \\
\text { index }\end{array}$ & Number & Mean & $\begin{array}{l}\text { Standard } \\
\text { deviation }\end{array}$ & Minimum & Maximum \\
\hline Resiliency & 180 & 78.53 & 10.50 & 55 & 101 \\
\hline $\begin{array}{l}\text { Instability of } \\
\text { marriage }\end{array}$ & 180 & 25.30 & 6.13 & 15 & 39 \\
\hline
\end{tabular}

Table 1 shows the descriptive indicators in the studied variables of which Mean is central tendency index and the standard deviation is central score distribution index.

Table 2: Test of assuming normal distribution of variables

\begin{tabular}{|l|l|l|}
\hline \multicolumn{1}{|c|}{ Statistical index } & Kolmogorov -Smirnov Z & Significance level \\
\hline $\begin{array}{l}\text { Resiliency } \\
\begin{array}{l}\text { Instability of marriage (the } \\
\text { probability of divorce) }\end{array}\end{array}$ & 1.29 & 0.85 \\
\hline
\end{tabular}

As it can be inferred from the results of Table 2, since the significance level obtained in the test (K-S) was more than 0.05 in the studied variables, as a result, it can be said that the distribution of the studied variables in the sample is normal. Therefore, the hypotheses of the study through parametric tests (Pearson correlation and regression analysis) were tested.

Also, the normality of the distribution of the variables was evaluated using appropriate statistical test. 
The Relationship between Resiliency Index and Instability of the Marriage in Women: A Correlational Design

Table 3: The results of Pearson correlation coefficient between resiliency and the likelihood of divorce

\begin{tabular}{|l|l|l|l|}
\hline Variable & $\mathbf{R}$ & $\mathbf{R}^{2}$ & Significance level \\
\hline $\begin{array}{l}\text { The relationship of } \\
\text { the resiliency and the } \\
\text { likelihood of divorce }\end{array}$ & $-0.522 *$ & 0.272 & 0.01 \\
\hline
\end{tabular}

* Significant correlation in the significance level of 0.01

As it can be seen from Table 3, using Pearson correlation coefficient, there is a significant negative relationship between the resiliency and the instability of marriage in the students in the significance level of 0.01 . In other words, it can be concluded that whatever people earn higher scores in resiliency, therefore they will be less likely to divorce, and vice versa.

\section{DISCUSSION AND CONCLUSION}

This study showed that there is an inverse relationship between the resiliency of and the probability of divorce; as a result, increasing in the resiliency could reduce the probability of divorce in couples. The obtained results in this study are consistent with the results Shahsavari (2013), Zolfaghari (2013), Poorsardar et al, (2012), Mikaeili et al, (2012), Jafari (2012), Zamiri Nezhad (2012), Abolghasemi (2011), Seydi (2011), Khalatbari and Bahari (2010), Mohyeldin et al. (2013), Richardson (2011), Friborg, oddgerir, Barlang, Dag et al. (2008), Elizabeth et al (2006).

Generally, it can be said that resilience capacity and the ability of people to stay healthy, tolerance and growing in difficult conditions or to modify the conditions are difficult, this process is not created spontaneously unless the person does the best facing with unpleasant and difficult conditions to get rid of it or getting less damages of it and attempt to discover and apply the protection of individual and environmental factors inside and outside that there is always the potential for it (Dinner et al., 2009). Masten (2006) stated that poor social and economic status, stressful life events, physical or emotional harms, and social harm in the family increases the risk for divorce, and can be changed the resiliency. As a result, high levels of resiliency in the couples reduces the probability of divorce occurrence, which this study has been suggested the same thing.

\section{Acknowledgments}

The author appreciates all those who participated in the study and helped to facilitate the research process.

\section{Conflict of Interests}

The author declared no conflict of interests. 


\section{The Relationship between Resiliency Index and Instability of the Marriage in Women: A Correlational Design}

\section{REFERENCES}

Abolghasemi, A. 2011. The relationship between the resiliency, self-efficacy, stress and life satisfaction in students with high and low academic achievement. Psychological Studies of Faculty of Education and Psychology of Alzahra University, 7 (3), 131-150.

Bahari, F. 2012. The effect of communication skills training on reducing the marital conflicts of couples competing for divorce. The researches of clinical and counseling psychology, 7(1): 0-59.

Bankipour, AH., Masoudinia, Z. 2012. An introduction to the marriages of young people in Iran.

Chaboki, O. 2013. Intergenerational study of the relationship between attitude toward divorce and family functions in women of Tehran. Women and Family Studies, 1 (1), 159-185.

Jafari Roshan, F. 2012. Effectiveness of group training based on positive psychology on resiliency, happiness and general health in women with a dependent spouse drugs in Qods Province. (MSc Thesis) Allameh Tabatabai University.

Khalatbari, J., Bahari, S. 2010. The relationship between resiliency and life satisfaction. Journal of Educational Psychology, 1 (2), 83-94.

Mikaeili, N., Ganji, M., Talebi Joybari, M. 2012. Comparison of resiliency, marital satisfaction and mental health in parents of children with learning disabilities and normal children. Journal of Learning Disabilities, 2 (1), 120-137.

Navabi Nezhad, Sh. 2010. Effectiveness of training to deal with deterministic thinking in improving marital relations in women. Quarterly of thought and behavior, 4(16).

Saeedeh, Sh. 2013. The evaluation of the relationship between identity and resiliency in students with the meaning of life. MSc Thesis, Tehran University.

Salimi Bajestani, H., Delavar, A. 2010. Comparing the effectiveness of counseling in the way of Adler method and cognitive restructuring based on analogies, on resiliency of the students. The journal of psychology counseling and psychotherapy, (1): 49 p.

Seyedi, MS., Pour Ebrahim, T., Bagherian, F., Mansour, L. 2011. The relationship between spirituality and resiliency of the families, the quality of communication in family mediation. Psychological methods and models, 2 (5), 63-79.

Zamiri Nezhad, S. 2012. Comparing the effectiveness of resiliency training group and group cognitive therapy on depression in dormitory girls. MSc Thesis, University of Allameh Tabatabai.

Zolfaghari, Sh. 2013. Analysis of researches on the causes affecting on divorce. MSC Thesis.

How to cite this article: N Mahdinia, S Nezhad (2016), The Relationship between Resiliency Index and Instability of the Marriage in Women, A Correlational Design, International Journal of Indian Psychology, Volume 3, Issue 4, No. 58, ISSN 2348-5396 (e), ISSN: 2349-3429 (p), DIP: 18.01.047/20160304, ISBN: 978-1-365-24976-1 